\title{
Erratum zu: Unrestringierte Optimierung
}

\section{Erratum zu:}

\section{Kapitel 2 in: O. Stein, Grundzüge der Nichtlinearen Optimierung,}

https://doi.org/10.1007/978-3-662-62532-3_2

Auf Seite 97 wurde in der letzten Zeile im Nenner der Formel „, $\mathrm{B}^{\mathrm{k} \text { “ }}$ durch „, $\mathrm{B}^{\mathrm{k}} \mathrm{y}^{\mathrm{k} \text { “ }}$ ersetzt, und auf Seite 105 wurde die Kursivierung in der Bemerkung 2.2.63 entfernt. 